Accepted Date : 09 - 06-2021, Publish Date : 16-06-2021 Vol 01. Issue 01

\title{
Analysis and Design of Web-Based Billing Information System at the Employee Cooperative of PT. Spindo Karawang Factory
}

\author{
Anggi Elanda ${ }^{\mathrm{a} *}$, Rahmat Gunawan $^{\mathrm{b}}$, M. Wahidin ${ }^{\mathrm{c}}$, Budhi Santoso $^{\mathrm{d}}$

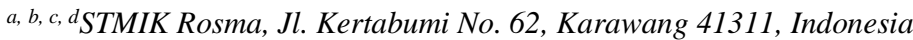 \\ *Corresponding author: anggi@rosma.ac.id
}

\begin{abstract}
In the digital era, people often call the era of the industrial revolution 4.0 demanding speed and accuracy in all fields. Moreover, the speed and accuracy in delivering and receiving information for decision making so as not to compete with competitors. The presentation of information is not only fast, accurate, it must also be easily understood by the person receiving the information. One business entity that must also take advantage of this technological development is a cooperative. In the cooperative PT. Spindo Karawang Factory transaction activities still have to be processed in Microsoft Excel, so that data duplication or inconsistency often occurs, data updates are not updated, there is no data backup and data that has not been integrated with other systems. The purpose of this research is to increase the effectiveness and efficiency of the transaction process in the cooperative. The research method used in this research is the System Development Life Cycle (SDLC) with the waterfall approach. The result of this research is the cooperative invoice information system of PT. Spindo Karawang Factory is web-based which is expected to be able to improve the process in the cooperative to be more effective and efficient.
\end{abstract}

Keywords : Analysis, Cooperative, Waterfall, Web

\begin{abstract}
Abstrak
Di era digital atau orang sering menyebut era revolusi industri 4.0 menuntut kecepatan dan ketepatan dalam segala bidang. Terlebih kecepatan dan ketepatan dalam penyampaian dan penerimaan informasi guna pengambilan keputusan sehingga tidak kalah bersaing dengan kompetitor. Penyajian informasi selain cepat, tepat juga harus mudah dipahami oleh orang yang menerima informasi tersebut. Salah satu badan usaha yang juga harus memanfaatkan perkembangan teknologi ini adalah Koperasi. Pada koperasi PT. Spindo Karawang Factory kegiatan transaksi masih harus diolah di Microsoft Excel, sehingga sering terjadi duplikasi atau inkonsistensi pada data, pembaharuan data yang tidak update, tidak ada backup (cadangan) data dan data yang belum terintegrasi dengan sistem lainnya. Tujuan penelitian ini adalah untuk meningkatkan efektifitas dan efisiensi proses transaksi pada koperasi tersebut. Metode penelitian yang digunakan dalam penelitian ini adalah System Development Life Cycle (SDLC) dengan pendekatan waterfall. Hasil dari penelitian ini adalah sistem informasi tagihan koperasi PT. Spindo Karawang Factory berbasis web yang diharapkan mampu meningkatkan proses dalam koperasi tersebut menjadi lebih efektif dan efisien.
\end{abstract}

Keywords : Analisis, Koperasi, Waterfall, Web

\section{Pendahuluan}

Di era digital atau orang sering menyebut era revolusi industri 4.0 menuntut kecepatan dan ketepatan dalam segala bidang. Terlebih kecepatan dan ketepatan dalam penyampaian dan penerimaan informasi guna pengambilan keputusan sehingga tidak kalah bersaing dengan kompetitor. Penyajian informasi selain cepat, tepat juga harus mudah dipahami oleh orang yang menerima informasi tersebut. Salah satu badan usaha yang juga harus memanfaatkan perkembangan teknologi ini adalah Koperasi. 
Koperasi merupakan gerakan ekonomi rakyat yang dijalankan berdasar atas asas kekeluargaan (menurut penjelasan UUD 1945). Menurut UU No.17 Tahun 2012 pasal 1 ayat 1, "Koperasi adalah badan hukum yang didirikan oleh orang perseorangan atau badan hukum Koperasi, dengan pemisahan kekayaan para anggotanya sebagai modal untuk menjalankan usaha, yang memenuhi aspirasi dan kebutuhan bersama di bidang ekonomi, sosial, dan budaya sesuai dengan nilai dan prinsip Koperasi”. Inti dari koperasi adalah kerja sama, yaitu kerja sama antara anggota dengan pengurus dalam usaha mewujudkan kesejahteraan anggota.

Koperasi karyawan PT. SPINDO Karawang Factory yang kemudian disingkat menjadi Kopkar PT. SKF pada awalnya bernama Koperasi Sejahtera Bersama didirikan pada tanggal 17 Juni 2012 yang kemudian karena permintaan pemilik perusahaan tempat koperasi ini bernaung akhirnya namanya dirubah menjadi Koperasi karyawan PT. SPINDO Karawang Factory.

Unit usaha yang dijalankan Kopkar PT. SKF diantaranya simpan pinjam dan retail. Sumber modal koperasi berasal dari dana patungan anggota yang bentuknya berupa iuran yang dibayarkan oleh anggota setiap bulannya. Karena berasal dari dana patungan dari banyak orang maka harus ada transparansi dan kemudahan mengakses informasi mengenai jumlah modal dan tagihan yang harus dibayar mengingat pembayaran masih bersifat konvensional atau setor tunai belum menggunakan sistem otomatis (payroll).

Anggota harus mendatangi kantor koperasi untuk mendapatkan informasi simpan pinjam, berupa simpanan, pendaftaran pinjaman dan tagihan potongan masih harus menunggu slip tagihan dibuat, slip tagihan dibuat oleh staf administrasi setelah mendapat laporan tagihan pinjaman uang dari bagian bendahara dan dari rekapitulasi transaksi harian yang sifatnya pembayaran tempo di toko. Dikarenakan keterbatasan waktu dari bagian bendahara dalam proses penyerahan data ke staf administrasi, juga perlu waktu dalam proses rekapitulasi pembayaran tunai dan tempo di toko seringkali slip tagihan terlambat diketahui anggota yang pada akhirnya terlambatnya pembayaran dari anggota bahkan tidak sedikit dari anggota yang menangguhkan pembayarannya dengan alasan uangnya sudah terpakai untuk kebutuhan yang lain, sehingga sering terjadi keluhan dari anggota. Proses pengelolaan rekap tagihan saat ini sudah terkomputerisasi, rekapitulasi harian di toko sudah menggunakan program akan tetapi belum terintegrasi atau terpisah dengan rekapitulasi pinjaman, jadi rekapitulasi bulanan yang nantinya mengeluarkan output berupa informasi tegihan masih harus diolah di Microsoft Excel, sehingga sering terjadi duplikasi atau inkonsistensi pada data, pembaharuan data yang tidak update, tidak ada backup (cadangan) data dan data yang belum terintegrasi dengan sistem lainnya.

Berdasarkan permasalahan di atas, maka dibutuhkan suatu sistem yang dapat mengembangkan sistem yang sudah ada dengan memanfaatkan fasilitas yang sudah ada dan menambahkan fasilitas yang dibutuhkan. Penelitian yang dilakukan oleh Eka W Fridayanthie (2016) [1], dan Diah Puspitasari (2015) [2] menggunakan metode waterfall telah terbukti dapat meningkatkan efisiensi dan efektifitas transaksi dalam sebuah koperasi. Sehingga penulis tertarik untuk melakukan analisis dan perancangan sistem koperasi simpan pinjam karyawan PT. Spindo Factory Karawang, dimana sistem yang akan di kembangkan bertujuan untuk mempermudah kinerja bagian administrasi dalam melakukan pengolahan data pinjaman dan data pembayaran tempo, bagi anggota dapat melihat rincian transaksi dan total tagihan atau total hutang secara online melalui website.

\section{Tinjauan Pustaka}

\subsection{Analisis}

Analisis adalah mencari suatu pola yang berkaitan dengan pengujian secara sistematis terhadap sesuatu untuk menentukan bagian, hubungan antar bagian dan hubungannya dengan keseluruhan [3]. Sedangkan pendapat lain mengungkapkan bahwa, nalisis adalah suatu usaha untuk mengurai suatu masalah atau fokus kajian menjadi bagian-bagian (decomposition) sehingga susunan/tatanan bentuk sesuatu yang diurai itu tampak dengan jelas dan karenanya bisa secara lebih terang ditangkap maknanya atau lebih jernih dimengerti duduk perkaranya [4].

\subsection{Sistem Informasi}

Sistem informasi adalah suatu sistem dalam suatu organisasi yang mempertemukan kebutuhan pengolahan transaksi harian yang mendukung fungsi operasi organisasi yang bersifat manajerial dengan kegiatan strategis dari suatu organisasi untuk dapat menyediakan kepada pihak luar tertentu dengan laporan-laporan yang diperlukan [5]. Sistem informasi merupakan kumpulan dari perangkat keras dan perangkat lunak 
komputer serta perangkat manusia yang akan mengolah data menggunakan perangkat keras memegang peranan yang penting dalam sistem informasi. Data yang akan dimasukkan dalam sebuah sistem informasi dapat berupa formulir-formulir, prosedur-prosedur dan bentuk data lainya [6].

\subsection{Koperasi}

Koperasi berdasarkan UUD Nomor 25 tahun 1992 tentang Perkoperasian bahwa koperasi adalah badan usaha yang beranggotakan orang-orang atau badan hukum koperasi dengan melandaskan kegiatannya berdasarkan prinsip koperasi sekaligus sebagai gerakan ekonomi rakyat yang berdasar atas asas kekeluargaan [7]. Koperasi adalah badan usaha yang beranggotakan orang-orang atau badan hukum koperasi dengan melandaskan kegiatannya berdasarkan prinsip koperasi sekaligus sebagai gerakan ekonomi rakyat yang berdasarkan atas asas kekeluargaan [8].

\subsection{Web}

Web adalah sebuah kumpulan halaman yang diawali dengan halaman muka yang berisikan informasi, iklan, serta program aplikasi [9]. Sedangkan pendapat lain mengatakan Web adalah suatu layanan sajian informasi yang menggunakan konsep hyperlink, yang memudahkan surfer (sebutan para pemakai komputer yang melakukan browsing atau penelusuran informasi melalui internet) [10]. Dari definisi diatas penulis menyimpulkan web adalah suatu layanan atau kumpulan halaman yang berisi informasi, iklan, serta program aplikasi yang dapat digunakan oleh surfer.

\section{5. $\quad$ Model Watrefall}

System Development Life Cycle (SDLC) Waterfall yaitu proses pengembangan atau mengubah suatu sistem perangkat lunak dengan menggunakan model-model dan metodologi yang digunakan orang untuk mengembangkan sistem-sistem perangkat lunak sebelumnya berdasarkan best practice atau cara-cara yang sudah teruji dengan baik [11].

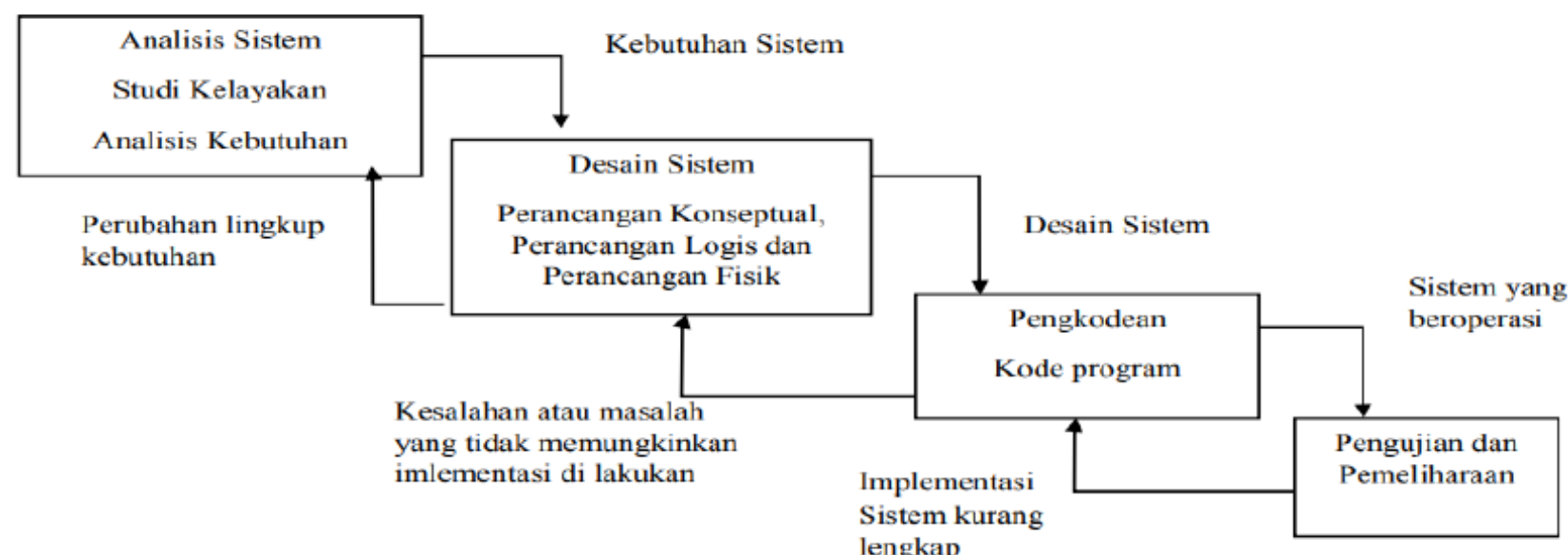

Gambar 1. System Development Life Cycle (SDLC) Model Waterfall Sumber: [11]

\section{Metode}

Penelitian ini menggunakan pendekatan Kualitatif yaitu penelitian yang berangkat dari data lapangan dan menggunakan teori yang sudah ada, lalu hasilnya akan memunculkan teori dari data tersebut. Pada penelitian ini, metode pengembangan sistem yang digunakan penulis adalah System Development Life Cycle (SDLC) Waterfall yaitu proses pengembangan atau mengubah suatu sistem perangkat lunak dengan menggunakan model-model dan metodologi yang digunakan orang untuk mengembangkan sistem-sistem perangkat lunak sebelumna berdasarkan best practice atau cara-cara yang sudah teruji dengan baik [12]. Adapun prosdur penelitian dalam penelitian ini adalah sebagai berikut.

a. Analisis Sistem 
Pada tahap ini kegiatan yang dilakukan adalah untuk mengetahui ruang lingkup sistem, permasalahan yang dihadapi pada sistem yang berjalan, kebutuhan pemakaian, dan solusi pemecahan masalah yang ada pada koperasi karyawan PT SPINDO Karawang Factory meliputi pendaftaran pinjaman, data anggota, transaksi anggota, dan informasi yang disampaikan pada anggota.

b. Desain Sistem

Metode perancangan yang akan digunakan oleh penulis dalam menyusun dan merancang sistem informasi pinjaman pada koperasi karyawan PT SPINDO Karawang Factory, mencakup perancangan flowchart, perancangan $D F D$, perancangan kamus data dan perancangan ERD. Tahap ini secara konseptual dilakukan perancangan beberapa sistem alternatif yang meliputi perancangan masukan, proses, keluaran, database, dan kontrol sistem.

\section{Hasil dan Pembahasan}

\subsection{Analisis Prosedur yang Berjalan}

\subsubsection{Simpanan Anggota}

a. Anggota

1) Mengisi slip setoran dalam rangkap 2.

2) Menyerahkan slip setoran lembar ke-1 dan lembar ke-2 kepada Bagian Simpanan.

3) Menerima slip setoran lembar ke-1 yang sudah diparaf dari Bagian Simpanan.

b. Bagian Simpanan

1) Menerima slip setoran lembar ke-1 dan lembar ke-2 yang sudah diisi dari Anggota, kemudian diparaf.

2) Menyerahkan slip setoran lembar ke-1 yang sudah diparaf kepada Anggota.

3) Mengecek metode pembayaran yang diajukan Anggota, apakah pembayaran tunai atau non tunai.

4) Jika metode pembayaran yang diajukan Anggota secara tunai, maka buat laporan simpanan tunai dalam rangkap 2, kemudian diserahkan kepada Supervisor untuk ditandatangan.

5) Jika metode pembayaran yang diajukan Anggota adalah non tunai, maka buat laporan simpanan non-tunai dalam rangkap 2, kemudian diserahkan kepada Supervisor untuk ditandatangan.

c. Supervisor

1) Menerima laporan simpanan tunai dan non-tunai dari Sekretaris, kemudian ditandatangan.

2) Menyerahkan laporan simpanan non-tunai lembar ke-1 kepada Sekretaris.

3) Berdasarkan laporan simpanan tunai, maka dibuat laporan simpanan tunai dan non-tunai, kemudian diserahkan kepada Ketua Koperasi.

d. Ketua Koperasi

Menerima laporan simpanan tunai dan non-tunai dari Supervisor. 


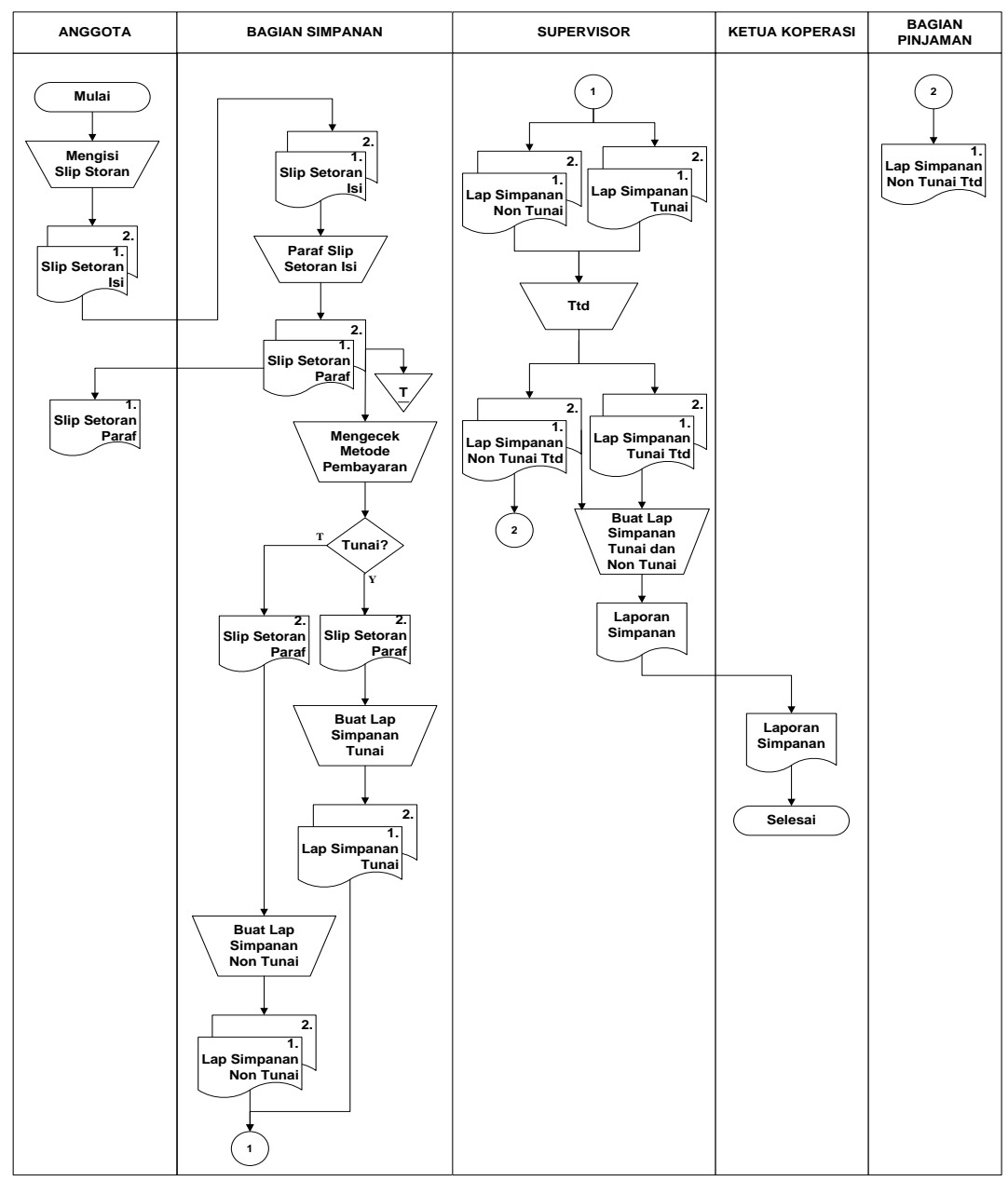

Gambar 2. Flow Document Simpanan Anggota

\subsubsection{Pinjaman Anggota}

a. Anggota

1) Mengisi formulir pengajuan kredit dalam rangkap 2.

2) Menyerahkan formulir pengajuan kredit kepada Bagian Pinjaman.

3) Menerima salinan formulir pengajuan kredit yang sudah ditanda tangan oleh Ketua koperasi dan slip angsuran lembar ke-1 dari Bagian Pinjaman

4) Menandatangani surat perjanjian, kemudian menyerahkan surat perjanjian lembar ke-2 kepada Bagian Pinjaman dan lembar ke-3 kepada Kasir.

5) Menerima slip angsuran lembar ke-1 dari Kasir.

b. Bagian Pinjaman

1) Menerima formulir pengajuan kredit yang sudah diisi dalam rangkap 2 dari Anggota.

2) Memeriksa kelengkapan isian formulir pengajuan kredit, jika tidak lengkap maka formulir pengajuan kredit dikembalikan kepada Anggota untuk dilengkapi. Jika lengkap formulir pengajuan kredit diserahkan kepada Ketua koperasi untuk dimintakan persetujuan.

3) Menerima formulir pengajuan kredit lembar ke-1 yang sudah ditandatangan Ketua Koperasi.

c. Supervisor

1) Menerima formulir pengajuan kredit yang sudah OK dari Bagian Pinjaman.

2) Memeriksa persetujuan kredit, jika tidak memenuhi syarat maka formulir pengajuan kredit ditolak. Jika memenuhi syarat maka formulir pengajuan kredit akan disetujui.

3) Menyerahkan formulir pengajuan kredit acc kepada Ketua Koperasi untuk ditandatangan.

4) Menerima formulir pengajuan kredit yang sudah ditandatangan dari Ketua Koperasi.

5) Menyerahkan formulir pengajuan kredit lembar ke-1 yang sudah ditandatangan Ketua Koperasi kepada Bagian Pinjaman dan lembar ke-2 diarsip menurut nomor. 
d. Ketua Koperasi

1) Menerima formulir pengajuan kredit yang sudah diacc dari Supervisor.

2) Menandatangani formulir pengajuan kredit, kemudian diserahkan kembali kepada Supervisor.

e. Kasir

1) Menerima surat perjanjian lembar ke-2 yang sudah ditandatangan oleh Anggota.

2) Membuat slip angsuran dalam rangkap 3, kemudian menyerahkan slip angsuran lembar ke1 kepada Anggota serta lembar ke-2 dan lembar ke-3 diarsip menurut nomor.

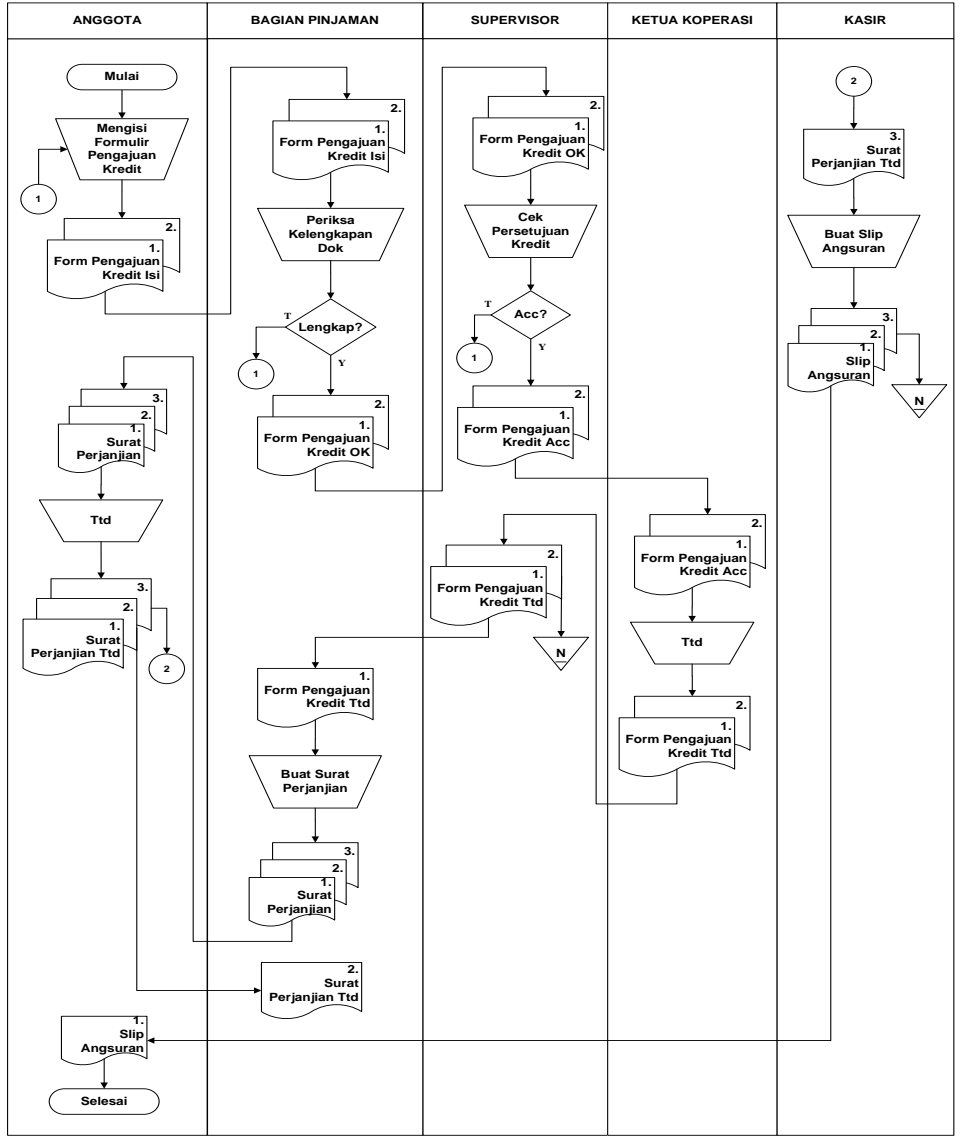

Gambar 3. Flow Document Pinjaman Anggota

\subsubsection{Transaksi Barang}

a. Anggota

1) Mengambil barang sesuai dengan kebutuhan.

2) Melakukan pembayaran dengan cara menyerahkan Kartu Tanda Anggota untuk di scan kepada bagian toko.

3) Menentukan jenis pembayaran (tunai/non tunai).

4) Menerima bukti pembayaran lembar ke-2 (tunai/non tunai).

b. Bagian Toko

1) Menerima Kartu Tanda Anggota untuk di scan dari anggota.

2) Mencatat transaksi yang dilakukan di warung ke PC.

3) Membuat bukti pembayaran dalam rangkap 2.

4) Memberikan bukti pembayaran rangkap ke-2 kepada anggota.

5) Merekap semua transaksi kedalam format yang telah ditentukan lalu menyerahkannya kepada Supervisor untuk diperiksa, setelah diperiksa oleh Supervisor kemudian diserahkan ke Bagian Kasir.

c. Supervisor

1) Menerima rekap transaksi dalam bentuk soft copy dari Bagian Toko. 
2) Memeriksa hasil rekapitulasi transaksi warung kemudian menyerahkannya kembali ke Bagian Toko.

d. Kasir

1) Menerima hasil rekapitulasi transaksi warung dari Bagian Toko yang sudah diperiksa oleh Supervisor.

2) Membuat slip tagihan dalam rangkap 3, kemudian menyerahkan slip tagihan lembar ke-1 kepada Anggota serta lembar ke-2 dan lembar ke-3 diarsip menurut nomor.

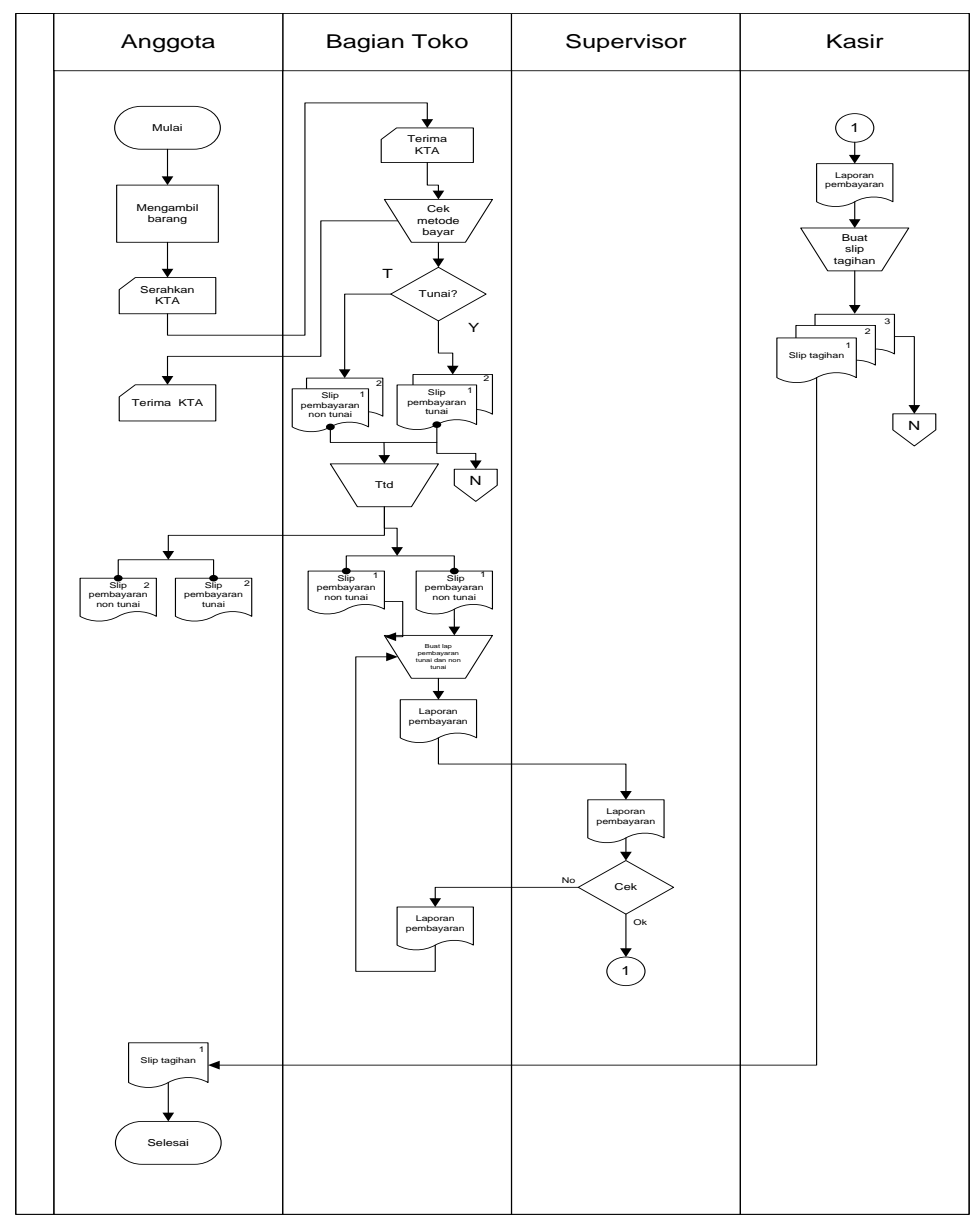

Gambar 4. Flow Transaksi Barang

\subsection{Prosedur Usulan}

\subsubsection{Simpanan Anggota}

a. Anggota

1) Input slip setoran pada sistem.

2) Melakukan pembayaran jika pembayaran dilakuakan secara tunai, kemudian Menerima slip setoran lembar ke-1 yang sudah diparaf dari Bagian Simpanan.

3) Informasi pembayaran dapat diakses pada sistem.

b. Bagian Simpanan

1) Menerima pembayaran sesuai data yang ada pada sistem, kemudian cetak slip setoran dalam rangkap 2, lalu diparaf.

2) Menyerahkan slip setoran lembar ke-1 yang sudah diparaf kepada Anggota dan lembar ke-2 diarsip berdasarkan tanggal.

3) Cetak laporan laporan simpanan tunai dan non tunai, masing-masing dalam 2 rangkap.

4) Menyerahkan laporan simpanan tunai dan non tunai kepada Supervisor untuk ditandatangan.

c. Supervisor

1) Menerima laporan simpanan tunai dan non-tunai dari Bagian Simpanan, kemudian ditandatangan. 
2) Menyerahkan laporan simpanan non-tunai lembar ke-1 kepada Bagian Pinjaman.

Berdasarkan laporan simpanan tunai dan non-tunai, maka dicetak laporan simpanan, kemudian diserahkan kepada Ketua Koperasi.

d. Ketua Koperasi

Menerima laporan simpanan tunai dan non-tunai dari Supervisor.

e. Bagian Pinjaman

Menerima laporan simpanan non-tunai lembar ke-1 dari Supervisor.

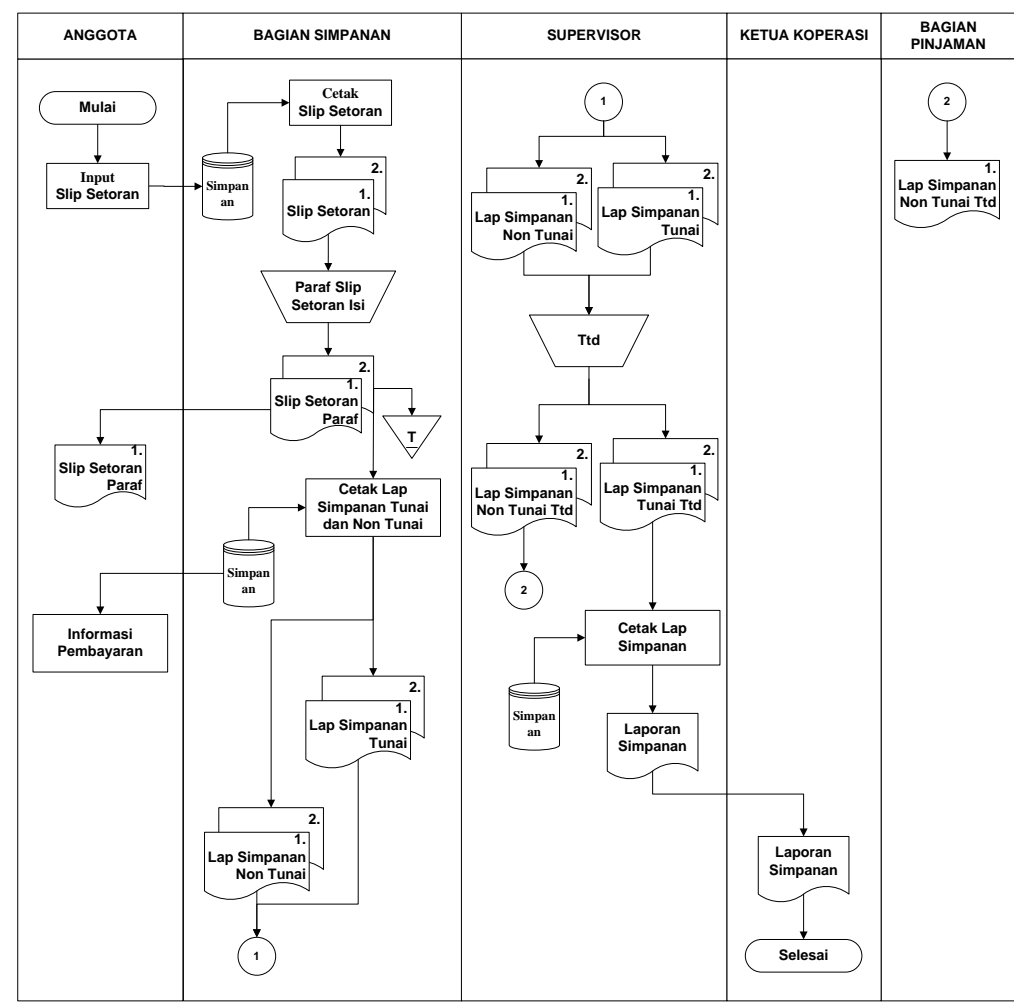

Gambar 5. Flow System Usulan Simpanan

\subsubsection{Pinjaman Anggota}

a. Anggota

1) Input pengajuan kredit pada sistem.

2) Menerima surat perjanjian dalam rangkap 3 dari Bagian Pinjaman.

3) Menandatangani surat perjanjian, kemudian menyerahkan surat perjanjian lembar ke-2 kepada Bagian Pinjaman dan lembar ke-3 kepada Kasir.

4) Menerima slip angsuran lembar ke-1 dari Kasir.

b. Bagian Pinjaman

1) Berdasarkan pengajuan kredit yang ada pada sistem, kemudian dilakukan input dan cetak pinjaman anggota dalam rangkap 2.

2) Menyerahkan pinjaman anggota kepada Supervisor untuk disetujui.

3) Menerima pinjaman anggota lembar ke-1 yang sudah ditandatangan Ketua Koperasi dari Supervisor.

4) Berdasarkan pinjaman anggota lembar ke-1 yang sudah ditandatangan Ketua Koperasi, kemudian dilakukan cetak surat perjanjian dalam rangkap 3.

5) Menyerahkan surat perjanjian kepada Anggota untuk ditandatangan.

6) Menerima surat perjanjian lembar ke-2 yang sudah ditandatangan oleh Anggota.

c. Supervisor

1) Menerima pinjaman anggota dalam rangkap 3 dari Bagian Pinjaman.

2) Memeriksa persetujuan kredit, jika tidak memenuhi syarat maka pinjaman anggota ditolak. Jika memenuhi syarat maka pinjaman anggota akan disetujui. 
3) Menyerahkan pinjaman anggota acc kepada Ketua Koperasi untuk ditandatangan.

4) Menerima pinjaman anggota yang sudah ditandatangan dari Ketua Koperasi.

5) Menyerahkan pinjaman anggota lembar ke-1 yang sudah ditandatangan Ketua Koperasi kepada Bagian Pinjaman dan lembar ke-2 diarsip menurut nomor.

d. Ketua Koperasi

1) Menerima pinjaman anggota yang sudah diacc dari Supervisor.

2) Menandatangan pinjaman anggota, kemudian diserahkan kembali kepada Supervisor.

e. Kasir

1) Menerima surat perjanjian lembar ke-2 yang sudah ditandatangan oleh Anggota.

2) Input dan cetak slip angsuran dalam rangkap 3, kemudian menyerahkan slip angsuran lembar ke-1 kepada Anggota serta lembar ke-2 dan lembar ke-3 diarsip menurut nomor.

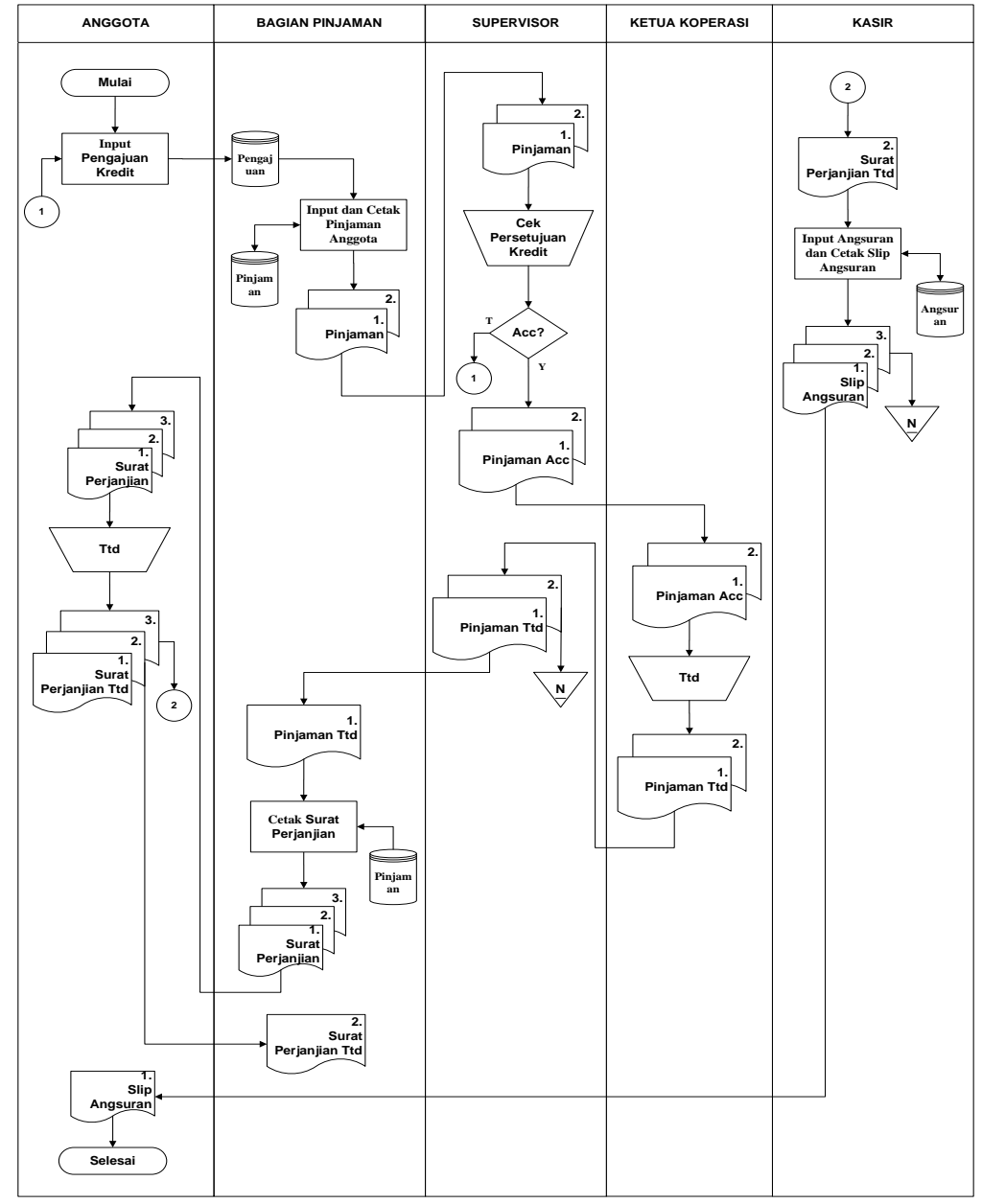

Gambar 6. Flow Document Pinjaman Anggota

\subsection{Rancangan Proses}

Rancangan proses yang merupakan tahapan umum teknik perancangan menggunakan Data Flow Diagram (DFD) dan Entity Relationship Diagram (ERD). 


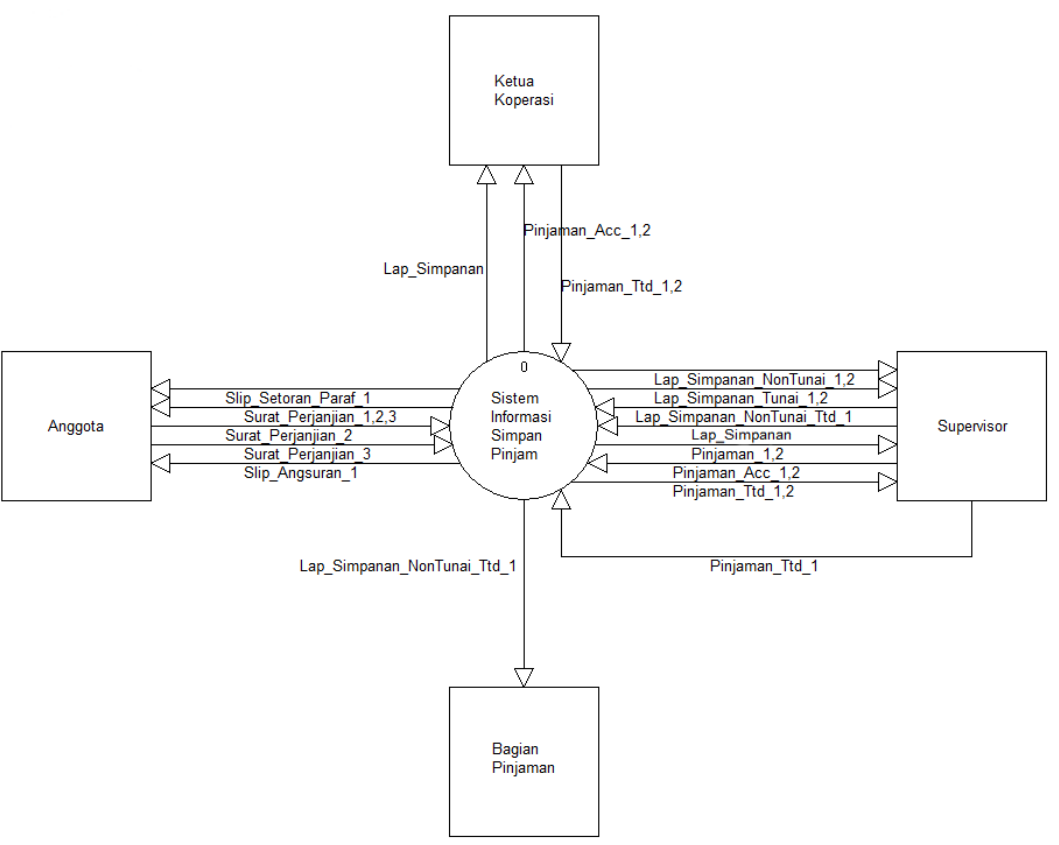

Gambar 7. Diagram Konteks

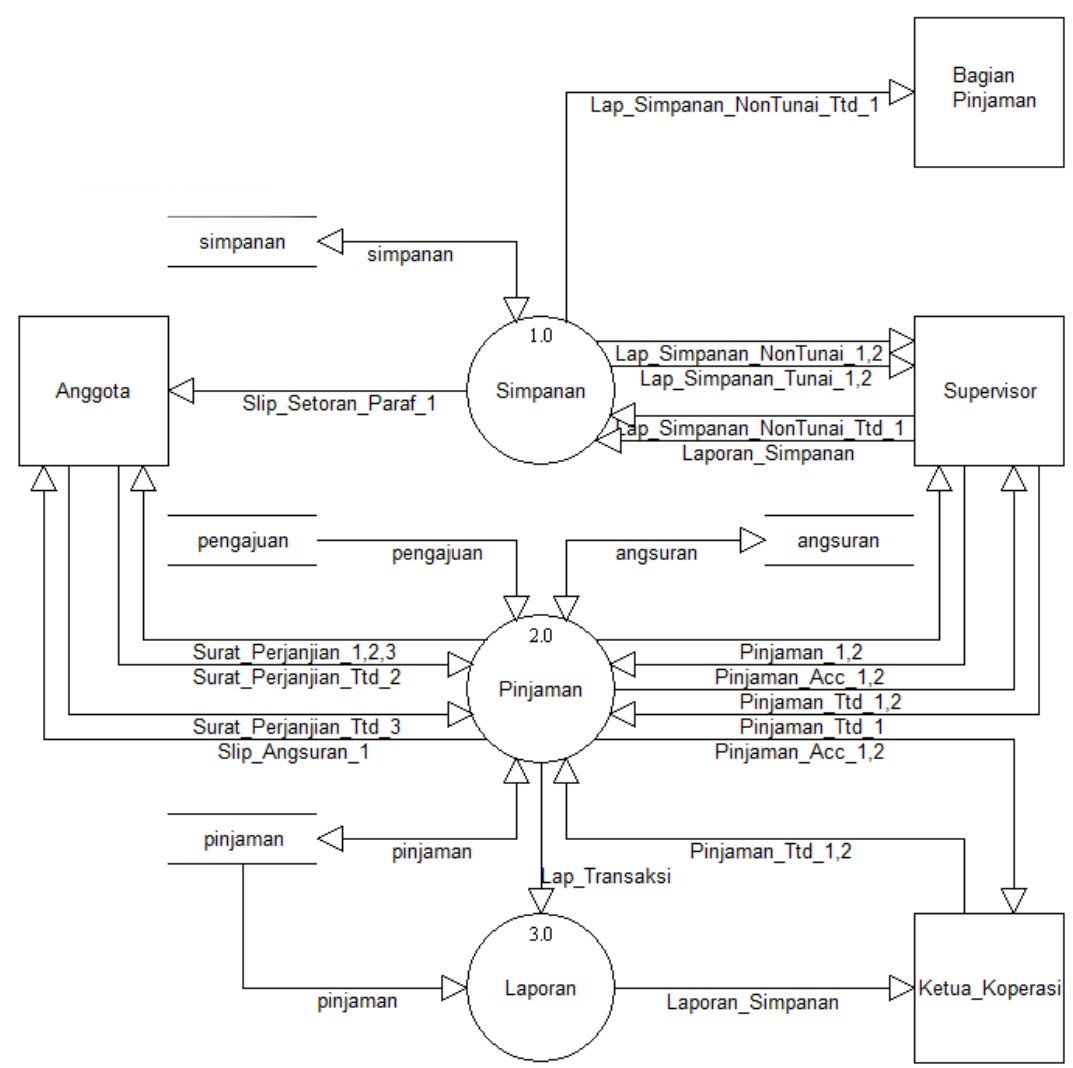

Gambar 8. Diagram Overview 


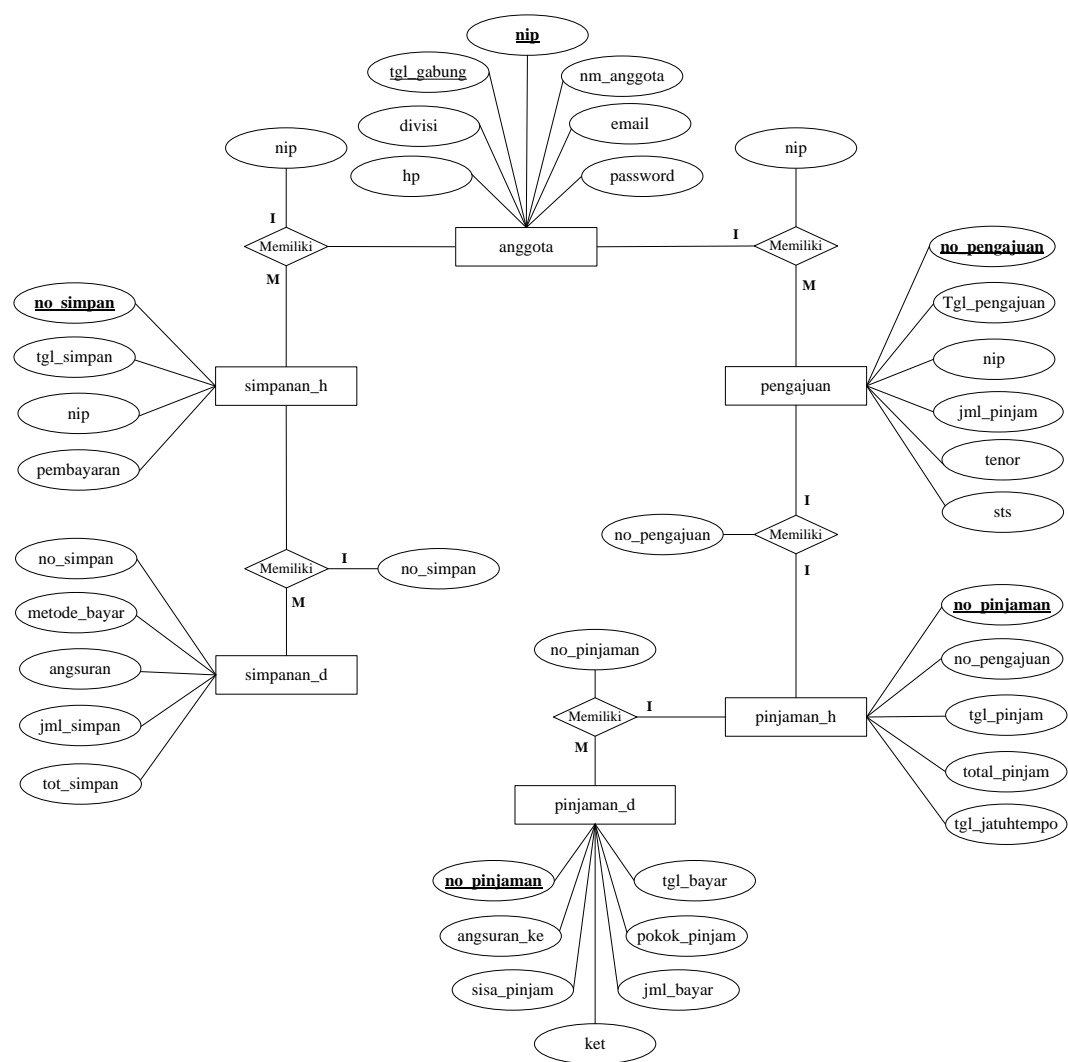

Gambar 9. Entity Relationship Diagram (ERD)

\subsection{Implementasi}

Tahap implementasi dimaksudkan untuk mengetahui sejauh mana tingkat keberhasilan perancangan sistem informasi simpan pinjam dan tagihan berbasis web ini di Koperasi Karyawan PT SINDO Karawang Factory sehingga program ini dapat berfungsi sesuai dengan tujuannya.

a. Tampilan Form Login

Form Login merupakan tampilan awal dari sistem informasi simpan pinjam berbasis web ini yang diperuntukan bagi petugas. Kegunaan dari tampilan ini adalah sebagai hak akses untuk masuk pada Form Menu Pengguna. Desain dari Form Login ini adalah sebagai berikut.

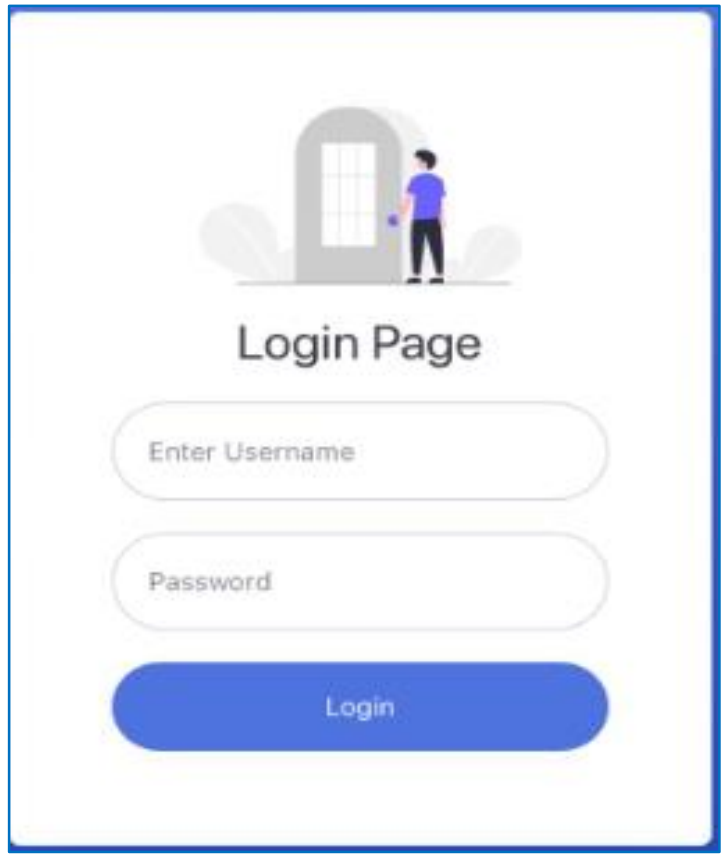

Gambar 10. Tampilan Form Login 
b. Tampilan Form Input Data Anggota

Form Input Data Anggota ini berfungsi untuk menyimpan dan mengelola data aggota koperasi. Tata cara pengisian, untuk NIP, nama anggota, email, nomor HP, dan password wajib diisi, sedangkan divisi dapat dipilih sesuai dengan pilihan yang ada pada sistem tersebut.

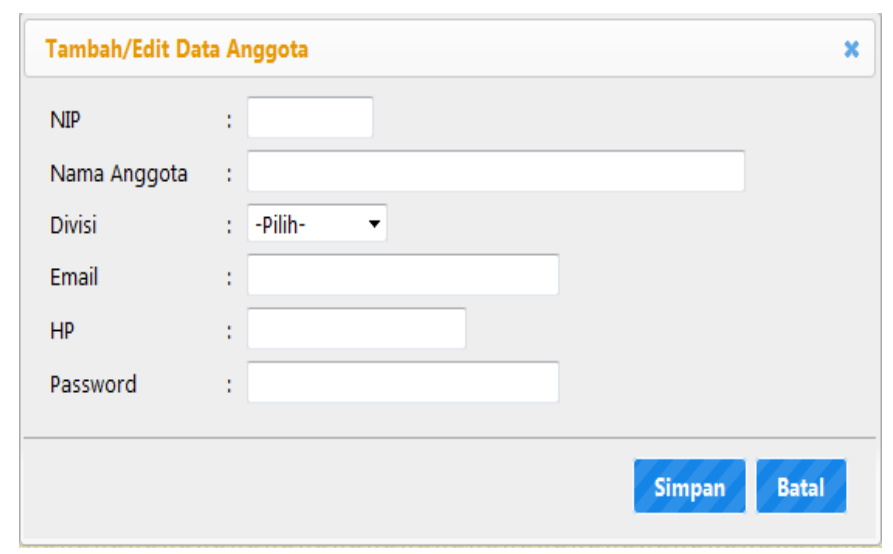

Gambar 11. Tampilan Form Input Data Anggota

c. Tampilan Form Input Data Penggajuan Pinjaman

Form Input Data Penggajuan Pinjaman ini berfungsi untuk menyimpan dan mengelola data pinjaman untuk anggota. Tata cara pengisian, untuk nomor pinjaman sudah otomatis dibuat oleh sistem, untuk tanggal pengajuan, NIP, dan jumlah pinjaman wajib diisi, sedangkan tenor dapat dipilih sesuai dengan pilihan yang ada pada sistem tersebut.

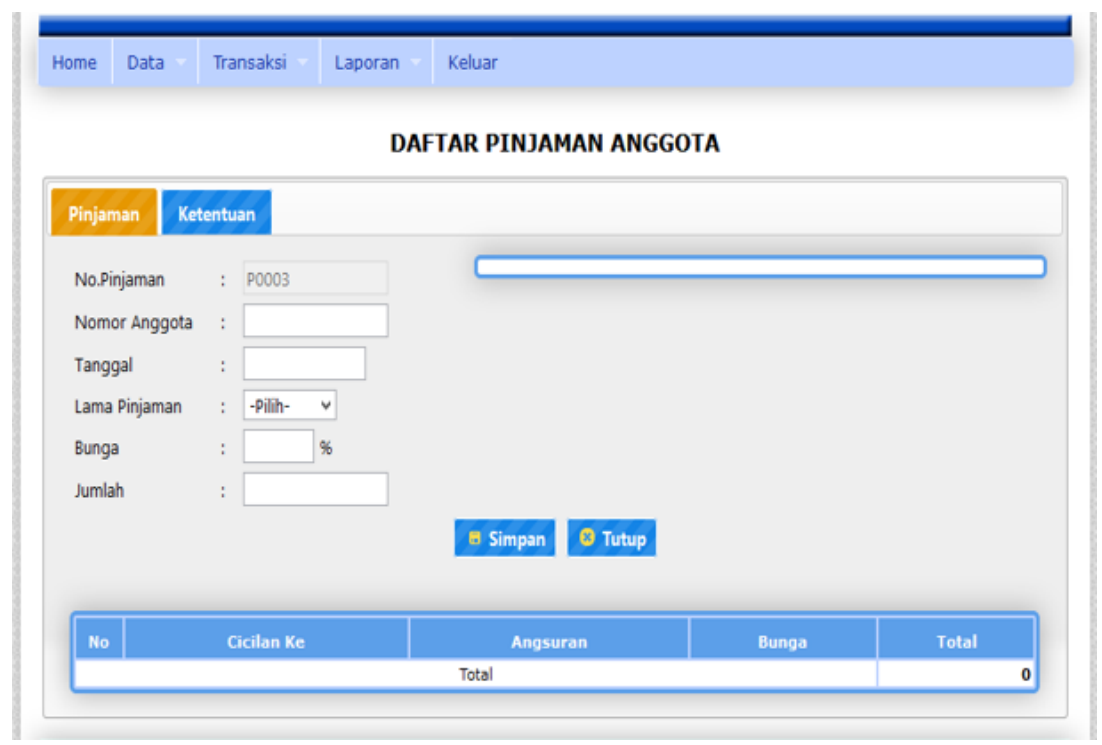

Gambar 12. Tampilan Form Input Data Pengajuan Pinjaman

d. Tampilan Form Input Data Simpanan Anggota

Form Input Data Simpanan Anggota ini berfungsi untuk menyimpan dan mengelola data transaksi setoran wajib oleh anggota koperasi. Tata cara pengisian, untuk NIP, tanggal setor, dan jumlah setoran wajib diisi, sedangkan metode pembayaran dapat dipilih sesuai dengan pilihan yang ada pada sistem tersebut. 


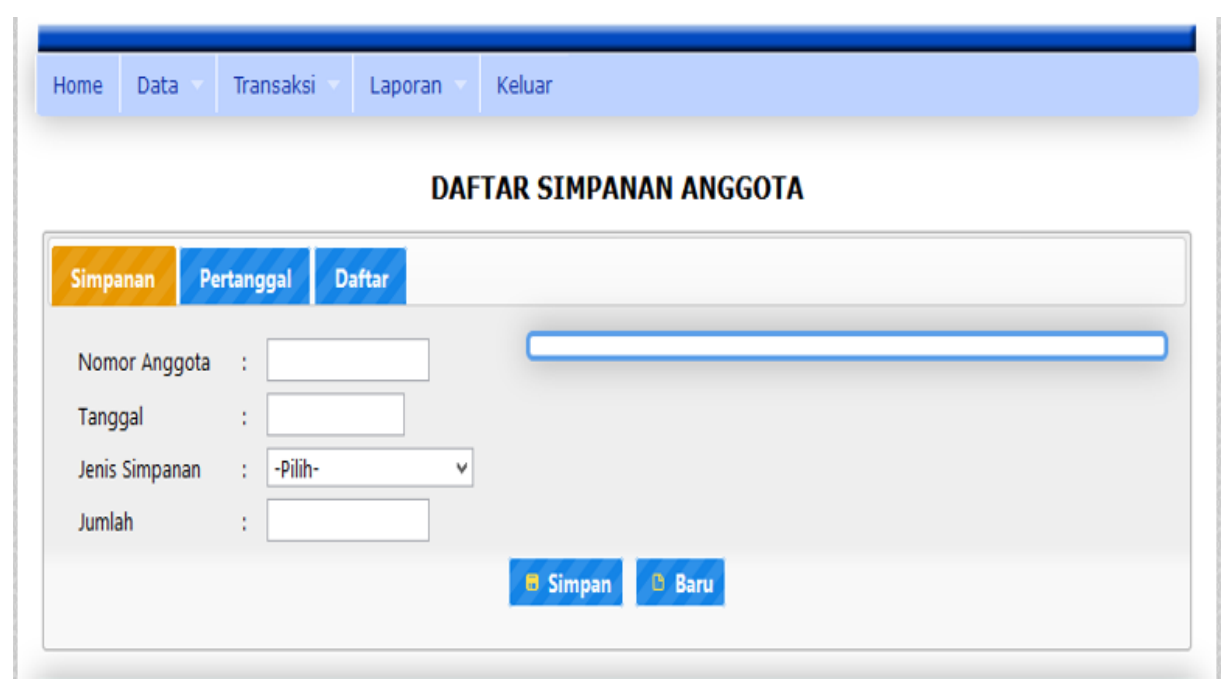

Gambar 13. Tampilan Form Input Data Simpanan Anggota

e. Hasil Tampilan Form Input Data Pinjaman dan Transaksi Anggota

Form Input Data Pinjaman Anggota ini berfungsi untuk menyimpan dan mengelola data transaksi pembayaran iuran wajib bulanan oleh anggota koperasi. Tata cara pengisian, cari nomor pinjaman, maka NIP, tanggal bayar, tenor, jumlah yang wajib dibayar akan tambil sesuai dengan nomor pinjaman yang diperoleh.

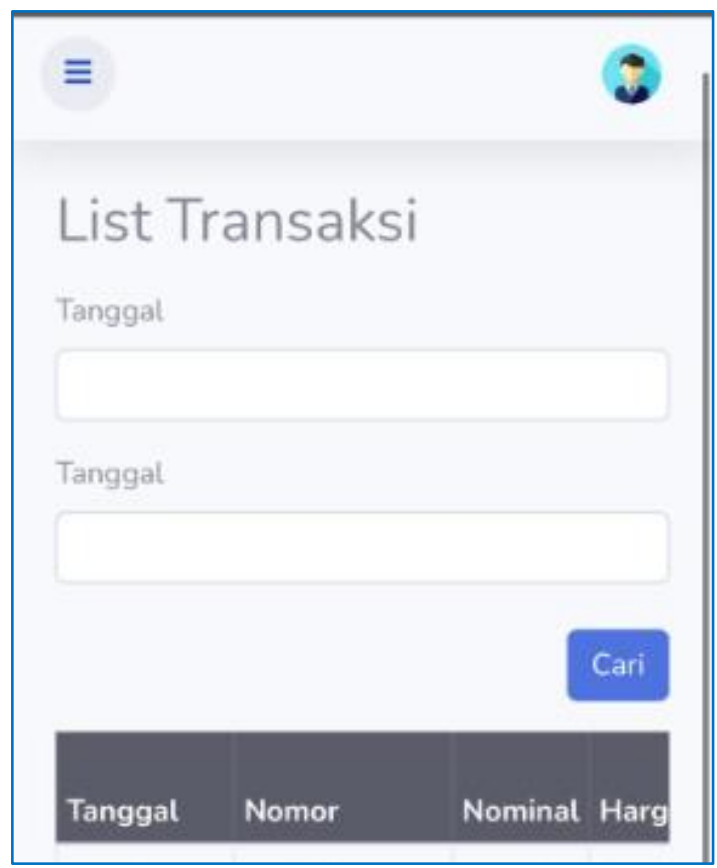

Gambar 14. Tampilan Form Input Data Pinjaman Anggota

\section{Kesimpulan \& Saran}

\subsection{Kesimpulan}

Berdasarkan hasil pengumpulan data analisis yang telah dilakukan, kegiatan transaksi pada koperasi karyawan PT. Spindo Karawang Factory masih menggunakan cara manual yaitu menggunakan Microsoft Excel untuk pengelohan data, sehingga rentan untuk terjadi kesalahan karena tidak terkomputerisasi dengan baik. Dengan adanya perancangan Sistem informasi koperasi simpan pinjam dan tagihan berbasis web ini memiliki database didalamnya sehingga data-data transaksi simpanan dan pinjaman anggota dapat tersimpan secara rapih dan aman. Sistem ini menyediakan informasi iuaran wajib dan tagihan pinjaman yang dapat diakses oleh anggota, maka anggota dapat mengetahui jumlah iuran wajib dan jumlah cicilan pinjaman yang telah dibayarakan melalui sistem. Serta diharapkan dengan adanya sistem ini untuk proses pencarian data lebih efektif dan efisien, sehingga memudahkan petugas dalam mengontrol data iuran yang belum dan yang 
sudah dibayarkan oleh anggota, dan memudahan petugas koperasi dalam pembuatan laporan serta meminimalisir kesalahan yang dapat terjadi pada koperasi simpan pinjam karyawan PT. Spindo Factory Karawang.

\subsection{Saran}

Berikut adalah saran yang dapat diberikan untuk pengembangan dari sistem informasi simpan pinjam berbasis web ini, yaitu:

a. Seharusnya untuk sistem informasi simpan pinjam berbasis web ini disediakan sistem validasi untuk mendeteksi kesalahan pengetikan, karena akibat kesalahan tersebut data yang telah dibuat harus perbaharui.

b. Kedepannya disediakan sistem untuk toko di Koperasi Karyawan PT SPINDO Karawang Factory sehingga supervisor dan ketua koperasi lebih mudah mengontrol seluruh kegiatan di Koperasi Karyawan PT SPINDO Karawang Factory.

c. Sistem informasi simpan pinjam dan tagihan berbasis web yang penulis usulkan ini masih perlu dikembangkan lebih lanjut ke depannya sesuai dengan masalah-masalah yang ada di perusahaan, sehingga dikemudian hari dapat disesuaikan dengan permintaan atau kebutuhan perusahaan, diantaranya dengan memaksimalkan informasi kesalahan input dan pencarian data.

\section{References}

[1] P. Pratiwi and A. Herliana, "Analisis Dan Desain Sistem Informasi Simpan Pinjam Pada Koperasi Sejahtera Bersama Bandung,” J. Inform., vol. 2, no. 1, 2016, doi: 10.31311/ji.v2i1.71.

[2] D. Puspitasari, "Rancang Bangun Sistem Informasi Koperasi Simpan Pinjam Karyawan Berbasis Web," J. Pilar Nusa Mandiri, vol. XI, no. 2, pp. 186-196, 2016.

[3] Sugiyono, Metode Penelitian Pendidikan Pendekatan Kuantitatif, Kualitatif, dan R\&D. Bandung: Alfabeta, 2014.

[4] D. Satori and A. Komariah, Metodologi Penelitian Kualitatif. Bandung: Alfabeta, 2013.

[5] T. Sutabri, Analisis Sistem Informasi. Yogyakarta: Andi, 2012.

[6] S. Mulyani, Sistem Informasi Manajemen. Bandung: Abdi Sistematika, 2016.

[7] "UNDANG-UNDANG REPUBLIK INDONESIA NOMOR 25 TAHUN 1992 TENTANG PERKOPERASIAN," Kemenkeu, 2021. [Online]. Available: https://jdih.kemenkeu.go.id/fulltext/1992/25TAHUN 1992UU.htm.

[8] B. Limbong, Pengusaha Koperasi : memperkokoh fondasi ekonomi rakyat. Jakarta Selatan: Margaretha Pustaka, 2012.

[9] A. Pipin, Kamus Teknologi Informasi. Bandung: Titian Ilmu, 2013.

[10] Y. K. Ardhana, PHP Menyelesaikan Website 30 Juta. Jakarta: Jasakom, 2012.

[11] R. A.S and M. Salahuddin, Modul Pembelajaran Rekayasa Perangkat Lunak (Terstruktur dan Berorientasi Objek). Bandung: Modula, 2011.

[12] R. A.S and M. Shalahuddin, Rekayasa Perangkat Lunak Terstruktur dan Berorientasi Objek. Bandung: Informatika Bandung, 2016. 